\title{
Social network analysis of e-complaints in fast food sectors in Turkey ${ }^{1}$
}

\author{
Deniz Yüncü ${ }^{2}$ \\ Hilmi Rafet Yüncü ${ }^{3}$
}

\begin{abstract}
Complaint is defined as an act of reflecting a dissatisfying situation to other side. Consumers act differently while they are expressing their dissatisfaction. Consumer complaints constitute an important feedback mechanism for companies. Thanks to these feedbacks, the firms get a chance to correct the mistake in the process of production and to produce a more satisfying product. Consumers express their complaints about the dissatisfying processes through feedback to the firm, expressing them to their friends, or resentment. With the developments in the Internet technology, it is seen that complaints have become widespread. Consumers let more people know about their complaints by expressing them in the internet environment. Therefore, the firms should attach importance to e-complaints and tolerate the dissatisfaction of their consumers. Although there are some studies about consumer complaints in the tourism area, there are not any studies about fast-food agencies. For this reason, it is aimed to categorize the fast-food agencies in www.sikayetvar.com.
\end{abstract}

Keywords: Customer complaints, e-complaints, fast food sector, social network analyse

\section{Introduction}

In competitive and complex environments, businesses frequently improve formal or informal relationships Consumer complaints constitute an important feedback mechanism for companies to monitor consumer satisfaction from their products and services (Sar1 et. al., 2013, p.561). Complaint shows up when there is a problem or there is an inconsistency between the consumer's expectations from a product and the product's intended use. One of the first conditions of consumer retention and long-term relationships with the consumers is satisfaction. Complaint is defined as expressing the dissatisfaction after the product trial to the third-parties or to the

\footnotetext{
1 Submitted in 4th International Interdisciplinary Business-Economics Advancement Conference (IIBA 2015).

2 Assistant Professor, Anadolu University, Faculty of Tourism, Department of Tourism Management, dkaragoz@anadolu.edu.tr

${ }_{3}$ Assistant Professor, Anadolu University, Faculty of Business Administration, Department of Hospitality Management, hryuncu@anadolu.edu.tr
} 
Yüncü, D. \& Yüncü, H. R. (2015). Social network analysis of e-complaints in fast food sectors in Turkey. International Journal of Human Sciences, 12(2), 235-243. doi: $10.14687 /$ ijhs.v12i2.3323

institutions (Lovelock \& Wright, 1999). However, the relationships may not always develop as the expectation of the firm, and there can be consumers who are facing problems. The firms should satisfy the consumers by solving their problems. A service which doesn't satisfy the consumer expectations and dissatisfaction with the product and the consumers' reporting their dissatisfaction to the firm or their friends result in two possible consequences. When the consumer expresses his dissatisfaction to the firm, it creates an opportunity for the firm to clear up the dissatisfaction and serve the consumers better. Besides that, the consumer's expressing the dissatisfaction will create a bad image for potential consumers. Therefore, complaint is an important and remarkable subject for all firms.

A lot of studies have been conducted on consumer complaints. Especially in the studies on tourism industry, the consumer complaints are examined and analysed (Litvin et. al., 2008; Boo \& Kim, 2013; Sparks \& Browing, 2010; Kozak, 2007; Sujithamrak \& Lam, 2005; Zheng et. al., 2009). The purpose of this study is to describe the complaints about fast-food categories and their relations with the brand on complaint websites which are important channels in gathering consumer problems and reporting to fast-food agencies. Also, e-complaints make inferences about the complaint management of the firms against the e-complaints. For this reason, sikayetvar.com is chosen because this website, which is active in Turkey, has high number of institutional members and complaints. On this website, the fast-food agency which has the most complaints were identified. Accordingly, fifteen fast-food agencies were identified.

\section{Consumer complaints}

Today's customers are better educated, more sophisticated, more demanding, and are willing to pay for services that meet or exceed their expectations (Sujithamrak \& Lam, 2005, p.290). There are many definitions about complaints. One of these definitions is that complaint can be defined as "an action taken by an individual which involves communicating something negative regarding a product or service". According to another definition, complaint is a reporting process of the consumers who is not satisfied of a product or service. These consumers can report their complaints to the firm and their friends. Consumers who directly report their complaints to the firm should define firm's problems (Pinto \& Mansfield, 2012). However, consumers are not always reporting their complaints to the firm. In such case, complaints are shared with friends. It is important to report complaints to the firm instead of sharing with friends for consumers who are not satisfied since the firm will have the opportunity of reviewing the quality of service and products as a result of the complaints. If the firm uses the opportunity and finds satisfactory solutions, consumer satisfaction will increase. However, if the firm cannot find satisfactory 
Yüncü, D. \& Yüncü, H. R. (2015). Social network analysis of e-complaints in fast food sectors in Turkey. International Journal of Human Sciences, 12(2), 235-243. doi: $10.14687 /$ ijhs.v12i2.3323

solutions, purchases may stop or this situation may affect consumers' friends in a negative way (Barıs, 2008, p.61-68). Customers' attitudes toward complaining, and the probability of achieving a successful outcome through complaining, have; therefore, been the main focus of research relating to customer-complaint behaviour (Petzer et. al., 2014, p.39). In their studies, Boo and Kim (2013) stated that negative word of mouth affects the potential consumers more than positive word of mouth. Complaints may provide greatest value to the companies which are especially in service industry (Sar1 et. al., 2013, p.561). Service failure severity has a significant influence on customers' attitudes towards complaining and complaint behaviours. It is important for organizations to afford customers the opportunity to complain - whenever a service failure occurs since depending on the severity there of, service failures could lead to dissatisfaction, negative word-of-mouth, anger and resentment on the part of customers, customers switching to competitors, or even retaliation (Petzer et. al., 2014, p.39). For services, complaints are more related with employees who play an active role in production process rather than products. A product which is purchased to satisfy any human need is expected to satisfy the expectations. If it cannot satisfy the expectations, dissatisfaction occurs. Complaints come true when these dissatisfactions are reported by different channels. Given that customer complaint behaviour and the subsequent resolution of a complaint play such a critical role in customer satisfaction and retention, retailers are increasingly expanding their customers' opportunities to complain, by offering innovative channels to voice their complaints, such as online complaining (Robertson, 2012, p.146). Researches show that the consumers whose problems are solved by employees are more satisfied than consumers who does not face with any problem (Hoffman \& Bateson, 2011).

More recently the Internet has provided various "new" ways to air a grievance, especially when little might have been done at the point of service failure. These grievances may be shared on websites where other consumers go to search and evaluate potential tourism purchases, such as accommodation. Such actions are akin to the consumer complaining behaviour of negative wordof-mouth WOM but done quite publicly (Sparks \& Browning, 2010, p.798). There are three main characteristics of information presented on Internet forums. First, the information has greater credibility than marketer-generated information. Second, the information from the Internet forums may be more relevant to customers. It has been found that the perception that a source is similar to the receiver can lead to an increased persuasive influence. Third, the information from the Internet forums generates greater empathy among readers. The information is provided through stories of personal experiences, which cause the readers to empathize with the feeling of the writer and create vicarious experience. Previous research shows potential customers pay more attention to word-ofmouth (WOM) because it is generated by people who are perceived as having no self-interest in 
Yüncü, D. \& Yüncü, H. R. (2015). Social network analysis of e-complaints in fast food sectors in Turkey. International Journal of Human Sciences, 12(2), 235-243. doi: $10.14687 /$ ijhs.v12i2.3323

promoting a product. Traditional WOM has proven to play a major role influencing customer buying decisions (Zheng et. al., 2009, p.719).

In the studies which are conducted before the development of the internet technologies discussed, Singh (1988) examined the complaints in three categories. These categories are reporting the complaint directly to the place where the service is purchased. First, consumers make an application to complain directly to the firm if they are not satisfied. Second, consumers tell their problems or dissatisfactions to the people around them. Third, consumers boycott personally to express their dissatisfaction and complaints about a brand or other services which are related to that brand that they purchased by not purchasing anymore (Singh, 1988, p.95). By development of the internet technologies, it has been seen that there are some changes in consumer complaints. Especially the complaints that are made on the internet show that the second category which is mentioned by Singh (1988) is developed and become common. However, as distinct from Singh's (1988) study, people can share their problems with not only their friends and families but also any person who is related with a service or product.

The Internet provides consumers with an anonymous and easily accessible channel for negative WOM through airing viewpoints and/or making complaints known to others (Sparks \& Browning, 2010, p.798). Consumers and relationships are very important for firms that give services because that makes them to sell. If the relationship breakdown occurs between both sides, market loses too (Kozak, 2007, p.139). Thanks to the developments of technology, today's consumers are more informed about services and products, and also they reach information easily. The Internet enables consumers to share these experiences widely, whether positive or negative, with other potential customers and to offer their own consumption-related advice by engaging in eWOM (Boo \& Kim, 2013, p.24). Beside this, today's consumer is a part of production in the process of consuming and uses the media. Thanks to the internet, consumers improve themselves in terms of expressing themselves in virtual platform, creating sense of belongings, sharing and cooperation. Technological development offers consumers an opportunity of communicating in wide area network by the internet and social network. Internet changed the consumer behaviour incredibly. Researches show that consumer behaviour is affected by the internet especially after purchasing (Neale et. al., 2006; Rust \& Lemon, 2001).

In social media, every consumer creates their own channels, complains and shares the problems about the brands with everyone. This makes consumer complaints management important for institutions. Now, even one consumer's complaints in social media cause crisis for even giant brands in hours (Altun, 2012). In this respect, complaints forums and websites give opportunity for consumers to create their own complaints and firms to answer these complaints. 
Yüncü, D. \& Yüncü, H. R. (2015). Social network analysis of e-complaints in fast food sectors in Turkey. International Journal of Human Sciences, 12(2), 235-243. doi: $\underline{10.14687 / \text { ijhs.v12i2.3323 }}$

Complaints which are reported to the complaint websites allow people to get informed and learn the experiences of others who already bought a product and complains about that. These people who have not purchase anything yet, also learns the firm's solutions for those complaints. In this point, firms should care about these websites. In this kind of website, firms should answer the complaints about their products and find fast solutions for them by contacting the consumer (Alabay, 2012). These websites can be created by non-profit people who are called third party, also official institutions. They are also created by consumers who want to share their own problems by giving information and brand name. One of these websites is şikayetvar.com. In today's world, complaint websites which allow communicating via the internet gives the opportunity for consumers to report complaints and for firms to answer and find solutions to these complaints. (Doğru et. al., 2014).

\section{Methodology}

The survey data have been gathered by scanning the complaints about fast-food agencies in www.sikayetvar.com in May, 2015. The survey data have been gathered by scanning the complaints about cell phones in www.sikayetvar.com in May, 2015. At this time, the number of the complaints about fast-food agencies is 15.262. Complaint topics are based on the complaint topics in the site. In this direction, the complaint topics are defined as spoilage, order/delivery, product range, product-hygiene, quality-taste, cooking quality, portion, duration of service, presentation/service, serving materials, wrong product, call center, online services, web content, price and payment, campaign, staff behaviour, ad/sms.

In order to analyse the data of the research, a two-mode data matrix which has fast-food businesses in columns and complaint topics in rows is prepared. Social network analysis is performed with analyse programs such as Netdraw and UCINET 6.0 to find out the fast-food businesses, social network topology and features of the complaint topics. The topology which is constituted by businesses and complaint topics, and the positions of complaint topics which is defined in topology is identified with the help of the matrix. In order to reveal the similarity of the data matrix of fast-food businesses and complaint topics, correspondence analysis is performed. The correspondence analysis in social network analysis is a practical tool, especially for evaluating the structural similarities in 2-dimensional maps (Borgatti \& Everett, 1997).

\section{Empirical findings}

When network visual which is prepared considering the complaint topics and the fast-food businesses which are included to the research is studied, it is seen that the firms such as Burger 
Yüncü, D. \& Yüncü, H. R. (2015). Social network analysis of e-complaints in fast food sectors in Turkey. International Journal of Human Sciences, 12(2), 235-243. doi: $\underline{10.14687 / \text { ijhs.v12i2.3323 }}$

King, Domino's Pizza which have the widest network in terms of home delivery and the number of branches in Turkey are centred upon the left side of the network. These businesses, especially comparing to the other businesses, are busy about order/delivery, call center, use of internet. Therefore, it is thought that they have a lot of complaints about late delivery, online services, campaigns, SMS, and call center. On the contrary, the local businesses such as Simit Sarayi, Citir Usta, Tavuk Dunyasi which have a sparse network in contrast with chain business such as Arby's and Sbarro are centered upon the right side of the network.

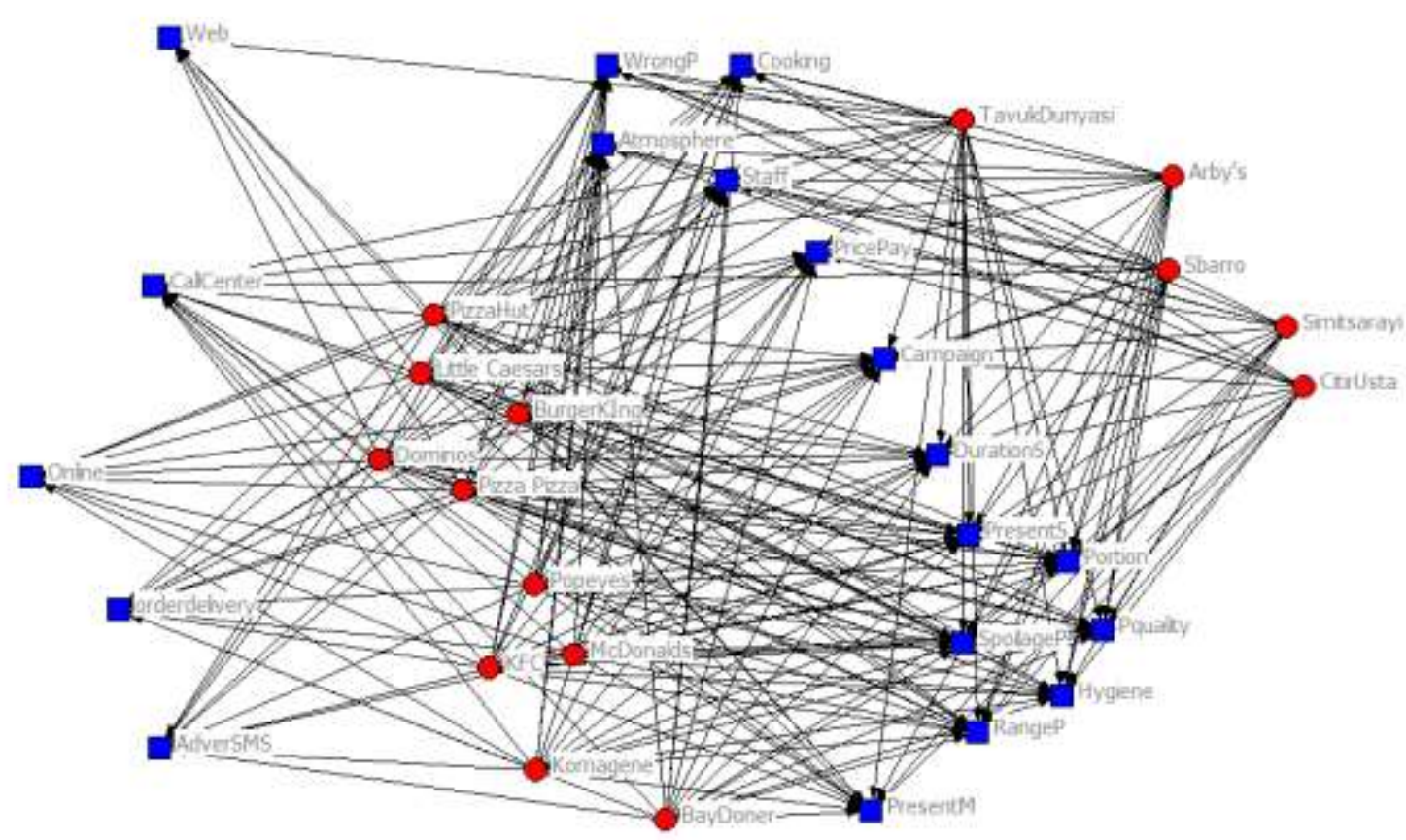

Figure 1. Network of fast-food business-complaint topics

When the correspondence analysis is performed to the fast-food businesses according to the number of complaints, it is seen that the businesses such as Burger King, Domino's Pizza, McDonalds, Pizza Pizza, Pizza Hut, Little Caesars, KFC are defined as the businesses with highrate of complaint (Figure 2). Popeyes and Bay Doner have average-rate complaint and Citir Usta, Sbarro, Tavuk Dunyasi, Simit Sarayi and Komagene are low-rate complaint businesses. 
Yüncü, D. \& Yüncü, H. R. (2015). Social network analysis of e-complaints in fast food sectors in Turkey. International Journal of Human Sciences, 12(2), 235-243. doi: $\underline{10.14687 / \text { ijhs.v12i2.3323 }}$

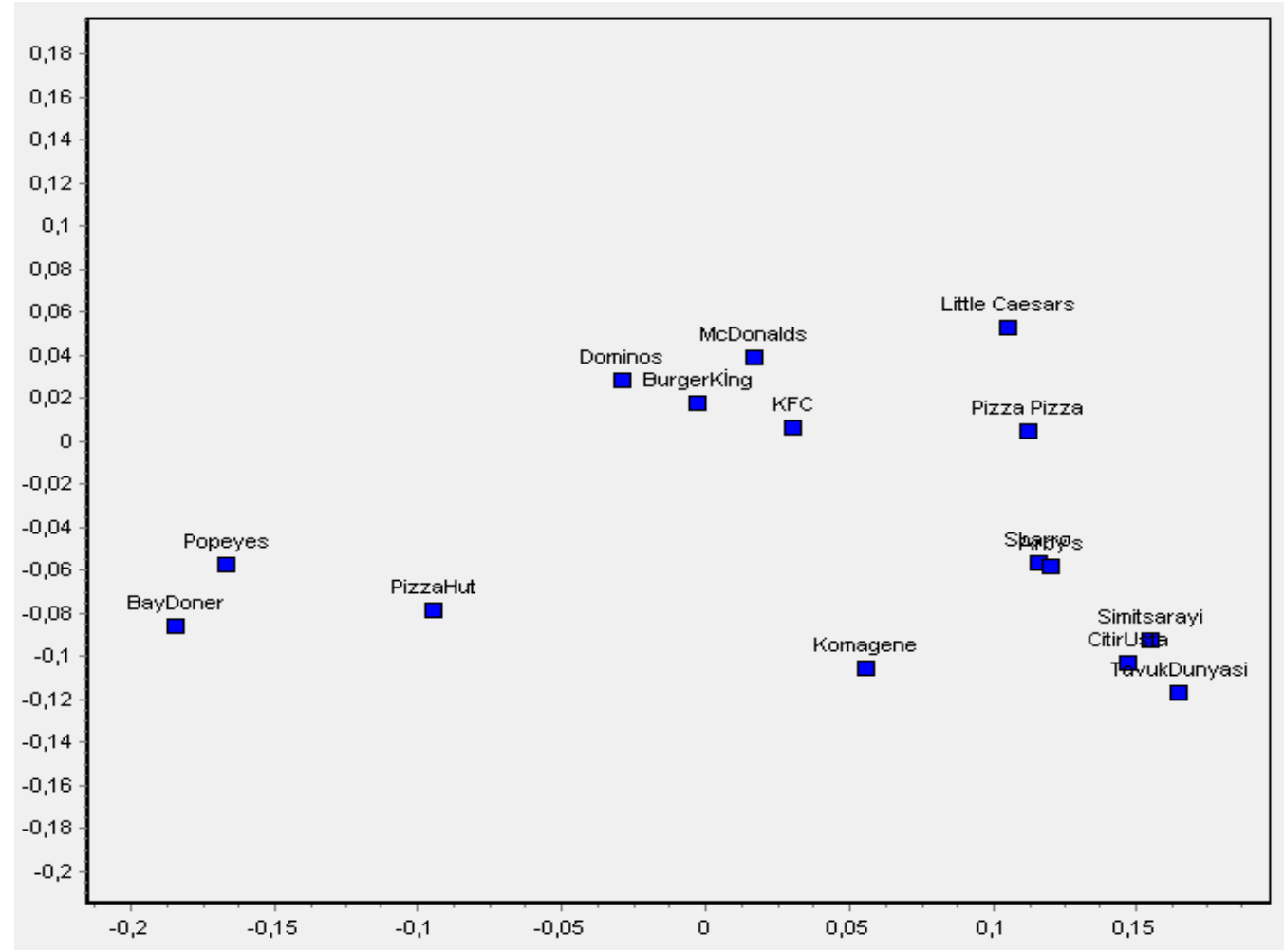

Figure 2. Correspondence analysis

The complaint management analysis is performed considering the number of complaints which the fast-food businesses receive and the number of complaints they answered (Table 1).

Table 1. Complaint management of the fast food business

\begin{tabular}{|l|c|c|c|c|}
\hline \multicolumn{1}{|c|}{ Enterprise } & $\begin{array}{c}\text { Total } \\
\text { complaints }\end{array}$ & $\begin{array}{c}\text { Answered } \\
\text { complaints }\end{array}$ & Ratio & Rank \\
\hline Domino's Pizza & 3536 & 225 & 6,36 & 5 \\
\hline Burger King & 2493 & 65 & 2,6 & 11 \\
\hline McDonald's & 518 & 17 & 3,28 & 8 \\
\hline Little Caesars & 587 & 56 & 9,54 & 2 \\
\hline Pizza Pizza & 354 & 14 & 3,95 & 7 \\
\hline KFC & 283 & 2 & 0,70 & 15 \\
\hline Popeye's & 169 & 2 & 1,18 & 13 \\
\hline Bay Doner & 132 & 20 & 15,15 & 1 \\
\hline Pizza Hut & 132 & 1 & 0,75 & 14 \\
\hline Tavuk Dunyasi & 97 & 4 & 4,12 & 6 \\
\hline Simit Sarayi & 90 & 6 & 6,66 & 4 \\
\hline Sbarro & 69 & 1 & 1,44 & 12 \\
\hline Arby's & 34 & 1 & 2,94 & 9 \\
\hline Komagene & 35 & 1 & 2,85 & 10 \\
\hline Citir Usta & 36 & 3 & 8,3 & 3 \\
\hline
\end{tabular}


Yüncü, D. \& Yüncü, H. R. (2015). Social network analysis of e-complaints in fast food sectors in Turkey. International Journal of Human Sciences, 12(2), 235-243. doi: $\underline{10.14687 / \text { ijhs.v12i2.3323 }}$

When the businesses are evaluated, Domino's Pizza has the most complaints. In total, Domino's Pizza answered only 225 of the complaints. According to the number of complaintsanswered complaints ratio, Domino's Pizza's rank in complaint management is 5th. Even though Burger King has 2493 complaints, they only answered 2,6 \%. Therefore, their rank is 11nd. Even though Bay Doner has 132 complaints, they are 1st in ranking because they answered 20 complaints. The detailed information about the rest of the businesses is in the table below.

\section{Conclusion}

Today, consumer feedback is an important mechanism for the businesses. The businesses need the consumer feedbacks for satisfying the expectations and clearing the troubles in the process. Therefore, the consumers need to convey their dissatisfaction to the enterprise or friends. With the developing technology and the social media's gaining importance in human life, the complaints spread more quickly to a wider area. The purpose of this study is to describe the complaint topics which are under the fast-food category in complaint sites which are important channel for gathering consumer problems and reporting them to the fast-food businesses, and their relations with the enterprise. The purpose, also, is to make inferences about the complaint management of the firms against the e-complaints. According to the findings, the businesses which have widest home delivery network, and use technology more frequently such as Burger King, Domino's Pizza receive more complaints about late delivery, call center, online services and campaigns.

On the contrary, the local businesses such as Simit Sarayi, Citir Usta, Tavuk Dunyasi which have a narrow network in contrast with chain businesses such as Arby's and Sbarro receive complaints mostly about the atmosphere, hygiene, staff behaviour and quality of the products. When it comes to the complaint management, it is seen that the businesses which are included to the study have answered few complaints although they have received more complaints. For this reason, it can be said that the success level of the businesses in complaint management is low. The basic limitedness of the study is that data has been gathered from only one complaint site and only the fifteen most complaint receiving businesses. Therefore, it is not possible to generalize the findings of the study.

\section{References}

Alabay, M. N. (2012). Müşteri şikâyetleri yönetimi. Uluslararası Yönetim İktisat ve İsletme Dergisi, 8(16)

Anderson, J. C., \& Gerbing, D. W. (1988). Structural equation modelling in practice: A review and recommended two-step approach. Psychological Bulletin, 103, 411-423. 
Yüncü, D. \& Yüncü, H. R. (2015). Social network analysis of e-complaints in fast food sectors in Turkey. International Journal of Human Sciences, 12(2), 235-243. doi: $\underline{10.14687 / \text { ijhs.v12i2.3323 }}$

Altun, F. (2012). Şikâyet Yönetimi, Marketing Türkiye, 15 Februbary.

Barış, G. (2008). Kusursuz müşteri memnuiyeti için şikâyet yönetimi. İstanbul: Mediacat.

Boo S., \& Kim, J. (2013) Comparison of negative e-WOM intention: An exploratory study. Journal of Quality Assurance in Hospitality \& Tourism, 14(1), 24-48.

Doğru, H., Kaygalak, S., Çavdarlı, M. C. \& Bahçeci, V. (2014). Engelli bireylerin turizm hizmetlerine yönelik e- şikâyetleri. Gaæi Üniversitesi Turiz̨m Fakültesi Dergisi, 2, 33-47.

Hoffman, D. L., \& Bateson, J. (2001). Essentials of services marketing: concepts, strategies, and cases. South-Western College Pub.

Kozak, M. (2007). Turizm sektöründe tüketicilerin şikâyetlerini bildirme eğilimleri. Yönetim ve Ekonomi, 14(1), 137-151.

Litvin, S. W., Ronald E. Goldsmith, R.E. \& Pan, B. (2008). Electronic word-of-mouth in hospitality and tourism management. Tourism Management, 29, 458-468

Lovelock, C. H., \& Wright, L. (1999). Principles of service marketing and management. PrenticeHall Inc., Upper Saddle River, New Jersey.

Neale, L., Murphy, J., \& Scharl, A. (2006). Comparing the diffusion of online service recovery in small and large organizations. Journal of Marketing Communications, 12(3), 165-181

Odabaşı, Y., \& Barış, G. (2002). Tüketici davranışı. İstanbul: Mediacat.

Petzer, D. J., Mostert, P.G., \& Fourie, S. (2014). Online complaint intention and service recovery expectations of clothing retail customers. The Retail and Marketing Review, 10-(2), 38-58

Pinto, M., \& Mansfield B., P. (2012). Facebook as a complaint mechanism: An investigation of millennials. Journal of Behavioral Studies in Business, 5(1)

Robertson, N. (2012). Self-service technology complaint channel choice: exploring consumers' motives. Managing Service Quality, 22(2), 145-164

Rust, R. T., \& Lemon, K. N. (2001). E-service and the consumer. International Journal of Electronic Commerce, 5(3), 85-101

Sarı, F.Ö., Alikılıç, Ö., \& Onat, F. (2013). E-complaining: analysis of lodging customers' ecomplaints from a Turkish internet website. International Conference on Information, Business and Education Technology (ICIBIT)

Singh J. (1988). Consumer complaint intentions and behavior: Definitional and taxonomical issues.. Journal of Marketing, 52(1), 93-107

Sparks, B.A. \& Browning, V. (2010). Complaining in cyberspace: The motives and forms of hotel guests' complaints online. Journal of Hospitality Marketing \& Management, 19(7), 797-818.

Sujithamrak, S., \& Lam, T. (2005). Relationship between customer complaint behavior and demographic characteristics: A study of hotel restaurants' patrons. Asia Pacific Journal of Tourism Research, 10(3), 289-307

Zheng, T., Youn, H., \& Kincaid, C.S. (2009). An analysis of customers' E-complaints for luxury resort properties, Journal of Hospitality Marketing \& Management, 18(7), 718-729 